\title{
BRITISH NORTH GREENLAND EXPEDITION SUMMARY OF GLACIOLOGICAL PROGRAMME
}

The British North Greenland Expedition under the leadership of Commander (L) C. J. W. Simpson, R.N., sailed from Deptford on July 8 for two years in Queen Louise Land.* The expedition comprises members of H.M. Forces, the Merchant Navy and a number of scientists. The main base is 60 miles $\left(97 \mathrm{~km}\right.$.) from the east coast at lat. $77^{\circ} \mathrm{N}$. The central station which is to be maintained for two years is to be at lat. $77^{\circ} \mathrm{N}$., long. $40^{\circ} \mathrm{W}$.

The senior member of the scientific team is Mr. R. A. Hamilton, and the subjects to be studied include Seismology, Gravimetry, Glaciology, Surveying, Meteorology, Geology, and Human Physiology.

A study of surface conditions of the ice sheet and of two outflowing glaciers is the basis of the glaciological programme in which regime is the dominant theme. Accumulation and ablation records are to be kept in conjunction with observations in micro-meteorology to find the proportionate influence of the different meteorological conditions in total ablation during different weather conditions, and the percentage influence of these meteorological factors in the penetration of the upper layers of snow and ice by the summer warming and the winter cold wave. The morphology of the ice is also linked with the micro-meteorology in the measurements to be made of the growth or decay of surface features such as moraines, dirt bands, dust wells and basins and, to a lesser degree, dead ice.

Movements of glaciers is not to be studied in detail, but it is hoped to record surface movement throughout the year by simplified photogrammetric measurements.

Temperature measurements of the air and ice-rock surface will be recorded in any convenient bergschrund.

On the sledge journeys from the base to the central station it is hoped to record a profile of the uppermost three metres of snow across the eastern half of the ice sheet by using a Rammsonde from the Swiss Snow and Avalanche Research Station on the Weissfluhjoch.

The glaciological work at the central station is more closely linked with the meteorological work than is possible at the base, since the base is 20 miles $(32 \mathrm{~km}$.) from the glaciological stations, whereas on the central plateau the work is at the same site and is complementary. The glaciologist will concentrate, as at base, on the conditions in the lowest two-metre air layer and the highest strata of snow and firn in order to establish an equation of the heat balance at the surface for the different seasons. Various modifications have been made to the hand-operated tubular drill as used by the Swedish glaciological stations in Kebnekajse, and by the Norwegian-SwedishBritish Antarctic Expedition (1949-52). With this type of drill it is hoped to reach to 20 metres depth for temperature measurements. To accompany these observations it is proposed to dig pits for analysis of the snow and to obtain firnification data.

The results of the work of the British North Greenland Expedition should, with those of the Danish Pearyland Expedition and the French Expedition to Greenland 1949-50, give a much more comprehensive picture of Greenland than has hitherto been available.

Reykjavik,

H. LISTER 16 fuly $195^{2}$

* Dronning Louises Land.

\section{GLACIER FLUCTUATION IN THE SWISS ALPS, I95 I}

The following data have been received from Dr. P-L. Mercanton :

$\begin{array}{cccccc} & & & \text { Advance } & \text { Stationary } & \text { Retreat } \\ \text { 1950 } & \ldots & \ldots & 4 \% & - & 96 \% \\ \text { 1951 } & \ldots & . & 12 \% & 9 \% & 79 \%\end{array}$

Dr. Mercanton thinks that the increased number of advancing glaciers may only be apparent and that the heavy avalanches during the winter season had hindered the normal melting processes.

Full details of the observations will be found in Die Alpen, Jahrg. 28, No. 8, 1952, p. 21 5-20. 